\title{
ВПЛИВ ТЕХНОЛОГІЧНИХ ПАРАМЕТРІВ ПРОЦЕСУ ЕЛЕКТРОХІМІЧНОГО ХРОМУВАННЯ НА ЕКСПЛУАТАЦІЙНІ ВЛАСТИВОСТІ ПОКРИТТІВ
}

\author{
Роп'як Любомир Ярославович \\ доктор технічних наук, професор \\ Івано-Франківський національний технічний університет нафрти і газу \\ ORCID: 0000-0002-9374-2550 \\ L_ropjak@ukr.net
}

\section{Шовкопляс Максим Володимирович} аспірант

Івано-Франківський національний технічний університет нафрти і газу ORCID: 0000-0002-5302-3623 maks.shovkoplias@gmail.com

Витвицький Василь Степанович кандидат технічних наук, доцент Івано-Франківський національний технічний університет нафрти і газу ORCID: 0000-0003-3682-1612 vytvytskyi.v.s@gmail.com

Стрілецький Юрій Йосипович доктор технічних наук, профеесор Івано-Франківський національний технічний університет нафрти і газу ORCID: 0000-0002-0105-8306 momental@ukr.net

Проведено аналіз методів хромування для підвищення зносостійкості та корозійної тривкості змінних деталей гідравлічної частини поршневих насосів: штоків поршнів, надставок штоків, плунжерів і циліндрових втулок. Об'рунтовано переваги застосування електрохімічного хромування деталей в проточному електроліті з нанододатками, яке забезпечує отримання зносостійких покриттів зі стабільними показниками якості поверхні та високими фрізико-механічними властивостями. Розроблено систему автоматизованого керування, яка забезпечує підтримання на заданому рівні технологічних параметрів процесу електрохімічного хромування в проточному електроліті: співвідношення концентрацій компонентів електроліту, швидкості потоку, густини струму та температури електроліту, а також дозволяє контролювати величину водневого показника електроліту та його електричного опору. Дослідили нанесення на зразки зі сталі 40ХH, які поверхнево гартували та шліффували, хромового покриття із стандартного електроліту з нанододатками. Визначали шорсткість поверхні, товщину і мікротвердість покриття. Хромовані зразки випробовували на зношування під час зворотно-поступального руху. Величину зносу визначали гравіметричним методом. Провели статистичну обробку результатів експерименту із застосуванням кореляційно-регресійного аналізу. Дослідили вплив масового співвідношення концентрацій компонентів електроліту, густини струму, швидкості потоку електроліту і температури електроліту на величину шорсткості, мікротвердості та зносу покриттів. Побудували регресійні моделі другого порядку, які описують залежності величини шорсткості поверхні, мікротвердості та зносу хромових покриттів від технологічних параметрів процесу. Встановлено, що зростання величини співвідношення концентрацій компонентів електроліту, швидкості потоку та густини струму призводить до зниження шорсткості, а збільшення температури електроліту спричиняє збільшення шорсткості хромового покриття. Технологічні параметри процесу хромування практично однаково впливають на збільшення величини мікротвердості та зменшення зношування покриття, а введення до складу хромового покриття нанооксидів алюмінію призводить до зростання його мікротвердості та відповідно, і зменшення зносу.

Ключові слова: електрохімічне хромове покриття, проточний електроліт, технологічні параметри, довгомірні деталі, автоматизована система керування, шорсткість, мікротвердість, зношування.

DOI https://doi.org/10.32845/msnau.2021.3.7

\section{Вступ}

Бурові насоси слугують для подачі під високим тиском на вибій свердловини промивальної рідини, яка забезпечує безперервне охолодження, мащення та промивання бурового інструменту, а також винесення на денну поверхню частинок зруйнованої буровим долотом гірської породи. Найбільшого поширення набули бурові поршневі насоси односторонньої дії, двосторонньої дії та плунжерні насоси, в тому числі штангові свердловинні насоси, в конструкції яких використовують довгомірні 
деталі. Деталі бурових насосів і штангових свердловинних насосів: штоки поршнів, надставки штоків, плунжери та циліндрові втулки експлуатуються в середовищі промивальної рідини із великою концентрацією твердих абразивних частинок гірської породи за дії високих тисків і температур та контактують із гумовими ущільненнями під час реверсивного тертя. Такі екстремальні умови експлуатації призводять до інтенсивного корозійно-механічного зношування деталей гідравлічної частини насоса. Для забезпечення під час буріння безперервної подачі промивальної рідини у свердловину в склад циркуляційної системи бурової установки входить два насоси, один із яких робочий, а другий - резервний. На протязі життєвого циклу бурових насосів необхідно періодично здійснювати заміну зношених деталей гідравлічної частини, які мають низький ресурс роботи, а це вимагає значних кількостей запасних частин (змінних деталей).

Серед різноманіття зміцнювальних технології, що застосовують для підвищення зносостійкості та корозійної тривкості змінних деталей бурових насосів, найбільшого розповсюдження набули: об'ємне гартування, поверхневе гартування струмами високої частоти, поверхневе пластичне деформування кульками та роликами, фрикційне зміцнення та нанесення різних типів зносостійких покриттів. Використання покриттів дозволяє раціонально поєднувати властивості матеріалів: деталь виготовляють із середньовуглецевої конструкційної сталі, а на її робочу поверхню наносять зносостійке покриття. Крім цього, покриття використовують як під час виготовлення нових деталей, так і під час відновлення зношених, що особливо актуально для змінних деталей бурових насосів. Тому дослідження, що спрямовані на розроблення технологічних процесів зміцнення покриттями деталей гідравлічної частини бурових насосів, є актуальними і мають вагоме наукове-практичне значення.

Аналіз останніх досліджень і публікацій

Для підвищення довговічності виробів машинобудування перспективним $є$ застосування функціонально орієнтованих технологій, які забезпечують формування поверхневих шарів з підвищеними фізико-механічними властивостями на робочих поверхнях деталей машин і механізмів. У дослідженні (Vinokurov et al., 2021) розглянуто розподіл електрохімічних покриттів за частотою їх нанесення на поверхні деталей у різних країнах: США, Японія, Італія, Франція, Німеччина, Великобританія, Іспанія, Канада, Мексика, Росія, ПАР. На основі аналізу, металеві покриття можна розташувати в ряд за спадною частотою їх нанесення: $\mathrm{Cr}>\mathrm{Ni}>\mathrm{Zn}>\mathrm{Cu}>\mathrm{Cd}$. Тобто найбільш часто використовують хромові покриття для підвищення зносостійкості деталей двигунів внутрішнього згорання, компресорів, поршневих і плунжерних насосів, гідро- і пнемоприводів, стволів стрілецької та артилерійської зброї тощо.

Автори (Zhang et al., 2013) провели аналіз причин виходу з ладу гідравлічних циліндрів, які $€$ найважливішим компонентом будівельної техніки. Оскільки від якості робочої поверхні штока залежить експлуатаційна надійність і термін служби гідравлічного циліндра, то для підвищення корозійної стійкості та зносостійкості штока пропонується використовувати гальванічні хромові покриття. Оцінили економічність технології хромування.

Основним конструктивним елементом стрілецької зброї є стволи, в яких внутрішня нарізна поверхня отвору швидко зношується (Ма, 2018), тому потребує захисного покриття. Покриття ствола хромом може ефективно покращити ерозійну стійкість ствола і, таким чином, збільшити термін його служби (Li, 2021).

У праці (Yusron et al., 2020) досліджували хромові покриття, нанесені на середньовуглецеву сталь ASSAB 618S для її захисту від корозії. На основі результатів цього дослідження зробили висновок, що температура електроліту, відстань між електродами впливають на швидкість корозії гальванічного твердого хромового покриття. Дослідження (Jeeva, 2020) присвячені електрохімічному хромуванню, де розглянуто процеси формування покриття та визначено його механічні властивості. Встановлено, що хромові покриття мають сітку мікротріщин, високу мікротвердість, стійкі до корозії та зносу, а також характеризуються низьким коефіцієнтом тертя.

У статті (Galimov et al., 2020) представлено порівняльне дослідження хромових покриттів, отриманих традиційним способом, а також шляхом поєднанням процесу гальванічного нанесення покриття 3 його механічною обробкою. Встановлено, що покриття, отримане гальвано-механічною обробкою (густина струму - 75 А/дм², температура розчину електроліту $-58^{\circ} \mathrm{C}$, час нанесення - 45 хв) не має дендритних дефектів. Мікротвердість покриття становить 960 ...990 HV.

Натепер гальванічні хромові покриття використовується в промисловості для підвищення корозійної стійкості, стійкості до стирання деталей машин (Vinh et al., 2018; Ngon et al., 2016). Хромування широко використовується під час реставрації зношених деталей (Xia et al., 2018). Однак хромове покриття впливає на втомну міцність деталей машин. Тому гальванічні хромові покриття доцільно використовувати для підвищення зносостійкості та корозійної тривкості деталей машин, але не для підвищення їх втомної міцності.

Серйозною проблемою $€$ те, що у виробничих процесах хромування використовується шестивалентний хром, який $є$ сильним токсикантом. Тому в останні роки інтенсивно ведуться дослідження, спрямовані на заміну електролітів шестивалентного хрому на тривалентний хром (Danilov et al., 2013; Protsenko et al., 2014; Protsenko et al., 2018). Показано (Bakanov et al., 2017), що для розробки нових технології електрохімічного нанесення хромових покриттів, необхідно виходити зі складної хімії $\mathrm{Cr}(\mathrm{III})$. Тонкі плівки хрому, а також плівки хрому, леговані кобальтом, отримують 3 формиат-гліцинового електроліту. Встановлено, що утворені плівки хрому яскраві та мають нанокристалічну структуру, а спільне осаджування хрому та кобальту призводить до утворення більш однорідної структури.

Автор (Katirci, 2016) досліджував вплив сахарину на фрізико-хімічні властивості хромового покриття і встановив, що сахарин робить можливим нанесення покриття за низької концентрації іонів $\mathrm{Cr}^{3+}$ у тривалентному хромовому електроліті. У дослідженнях (Liang et al., 2017; 
Hall et al., 2017) наведено властивості хромових покриттів, нанесених з електроліту $\mathrm{Cr}(\mathrm{III})$. Встановлено, що такі хромові покриття мають достатньо високу зносостійкість та корозійну стійкість. У праці (Qi et al., 2020) вивчали формування хромового покриття на алюмінії з електроліту з вмістом іонів тривалентного хрому.

Електрохімічному хромуванню в спокійному електроліті на постійному струмі присвячена велика кількість досліджень, зокрема (Sherwin et al., 2020). Досліджували нанесення твердого хрому (Putri et al., 2019) на елементи імплантанта суглоба 3 нержавіючої сталі 304, використовуючи метод Тагучі для проведення експерименту та отримання оптимальної товщини покриття. Встановлено, що найбільш значущими факторами для товщини гальванічного покриття є концентрація хромової кислоти та напруга, а найменш впливовим фактором - час.

У праці (Bikulčius et al., 2017) досліджено трибологічні властивості хромових покриттів, нанесених на нержавіючу сталь 316Tі з сульфатних ванн $\mathrm{Cr}$ (III) з комплексоутворювачами. Дослідження коефіцієнта тертя під час сухого зношування показали, що хромові покриття, нанесені у ванні $\mathrm{Cr}(\mathrm{III})$, мають кращі трибологічні властивості порівняно з покриттями $\mathrm{Cr}$, нанесеними із ванни $\mathrm{Cr}(\mathrm{VI})$.

Автори (Addach et al., 2007) провели оптимізацію процесу хромування в спокійному електроліті в імпульсному режимі з використанням центрального композиційного плану. Це дозволило визначити режими за яких досягається найвища мікротвердість покриття до і після старіння та найменша кількість закупореного водню.

Під час нанесення покриттів у спокійному електроліті не забезпечується рівномірне вкриття хромом, оскільки на катоді (деталь) осаджується металевий хром і виділяється водень, а також відновлюється шестивалентний хром до тривалентного, а на аноді - виділяється кисень і тривалентний хром відновлюється до шестивалентного. Тому для забезпечення постачання до поверхні деталі «нового» електроліту та інтенсифрікації газовідведення формують хромові покриття у проточному електроліті. B праці (Kagajwala et al., 2013) описана технологія та конструкція електрохімічної комірки для нанесення хромових покриттів на внутрішню поверхню труби в проточному електроліті, який містить тривалентні іони хрому. Дослідники (Ropiak \& Ostapovych, 2016) вивчали нанесення хромових покриттів у стандартному проточному електроліті на основі хромового ангідриду та сірчаної кислоти та провели оптимізацію технологічного процесу для забезпечення одержання зносостійких покриттів.

Автори (Belyaev et al., 2016) представили результати досліджень процесу протічного хромування внутрішніх поверхонь довгомірних циліндричних виробів із застосуванням електроліту з ультрадисперсними частинками алмазів із безперервним обертанням деталей. В ході експериментів були обрані такі змінні технологічні параметри: температура електроліту та частота обертання деталі. Встановлено вплив режимів електролізу на пористість, мікротвердість, товщину хромових покриттів та однорідність їх структури.

У праці (Sonntag et al., 2017) проведено випробовування хромових покриттів на металевих деталях шар- ніра суглоба зі сплаву $\mathrm{CoCr}$, які розробляли для підвищення їх зносостійкості. Як електроліти використовували: (a) промисловий стандартний хромовий електроліт; (b) електроліт шестивалентного хрому $\mathrm{Cr}(\mathrm{VI})$ зі зниженим вмістом триоксиду хрому $\left(\mathrm{CrO}_{3}\right)$, як без твердих добавок, так і (c) з додаванням наночастинок фулерену (C60); i (d) електроліт тривалентного хрому $\mathrm{Cr}(\mathrm{III})$ з додаванням С60. Встановлено, що знос шестивалентних хромових покриттів зменшився на 70-84 \% порівняно з еталонним підшипником $\mathrm{CoCr}-\mathrm{CoCr}$, тоді як покриття, одержане з тривалентного хрому, навіть збільшило знос більш ніж на $300 \%$.

У доповіді (Yar-Mukhamedova \& Yar-Mukhamedov, 2012) представлені результати дослідження корозійної стійкості нанокомпозиційних електролітичних покриттів $\mathrm{Cr}_{-} \mathrm{SiO}_{2}$, нанесених на конструкційну сталь $17 Г 1 \mathrm{C}$. Випробовування в нафтовому розчині родовища «Жанажол» показали, що найвищу корозійну стійкість має хромове покриття, отримане за температури 333 К.

У праці (Bikulčius et al., 2018) було досліджено отримання композиційних покриттів з металевою матрицею $\left(\mathrm{Cr}-\mathrm{ZrO}_{2}\right)$ під дією постійного струму та вивчено їх захисні властивості. Композиційне покриття $\mathrm{Cr}-\mathrm{ZrO} 2$ наносили з електроліту на основі тривалентного сульфату з комплексоутворювачем, що містив різні концентрації частинок $\mathrm{ZrO}_{2}$. Результати досліджень показали, що частинки $\mathrm{ZrO}_{2}$ впливають на мікротвердість, морфологію та корозійну поведінку композиційних покриттів $\mathrm{Cr}-\mathrm{ZrO}{ }_{2}$, отриманих із електроліту $\mathrm{Cr}(\mathrm{III})$.

Дослідники (Zeng \& Zhang, 2008) наносили аморфні хромово-оксидалюмінієві (a-Cr-Al $\mathrm{O}_{3}$ ) композиційні електрохімічні покриття товщиною 50 мкм в електроліті $\mathrm{Cr}(\mathrm{III})$, що містили тверді частинки $\mathrm{Al}_{2} \mathrm{O}_{3}$ та $\mathrm{Al}^{3+}$. Встановлено, що $\mathrm{Al}^{3+}$ сприяє рівномірному розподілу частинок $\mathrm{Al}_{2} \mathrm{O}_{3}$ в хромових покриттях. Результати демонструють, що введення в електроліт 25 г/л частинок $\alpha-\mathrm{Al}_{2} \mathrm{O}_{3}$ значно покращує трибологічні характеристики покриттів $\alpha-\mathrm{Cr}$.

Аналіз літературних джерел присвячених електрохімічному хромуванню в проточному електроліті показав, що цей метод дозволяє наносити покриття за більш високих густин струму, і при цьому забезпечити рівномірне нанесення шару покриття з низькою шорсткістю, а також отримати високу швидкість нанесення покриття та підвищений вихід хрому за струмом. Однак наведені у технічній літературі дані не дають можливості цілеспрямовано здійснювати раціональний вибір технологічних параметрів процесу електрохімічного хромування в проточному електроліті з нанододатками для формування покриттів з високими експлуатаційними властивостями на циліндричних деталях.

У зв'язку із цим виникає необхідність встановлення впливу технологічних параметрів процесу електрохімічного хромування в проточному електроліті з нанододатками на показники якості поверхні та фрізико-механічні властивості хромових покриттів.

\section{Цілі та задачі дослідження}

Метою даної роботи є дослідження впливу технологічних параметрів процесу електрохімічного хромування в проточному електроліті з нанододатками на властивості покриттів нанесених на сталеву основу. 
Для досягнення поставленої мети були поставлені такі завдання:

- розробити систему автоматизованого керування установкою для електрохімічного хромування в проточному електроліті;

- дослідити вплив технологічних параметрів процесу електрохімічного хромування на шорсткість поверхні та фрізико-механічні властивості покриттів.

\section{Матеріали і методи досліджень}

Для дослідження впливу технологічних параметрів процесу електрохімічного хромування в проточному електроліті на експлуатаційні властивості сталевих циліндричних деталей використовували розроблений технологічний процес та установку, яка споряджена системою автоматизованого керування та містить електрохімічну комірку. Зразок під час нанесення хромового покриття встановлюють вертикально в електрохімічній комірці та герметизують.

Розроблена система автоматизованого керування під час проведення електрохімічного хромування робочих поверхонь деталей забезпечує встановлення та вимірювання технологічних параметрів процесу: співвідношення концентрацій компонентів електроліту (хромового ангідриду та сірчаної кислоти), швидкості потоку електроліту в кільцевій протоці між хромованою поверхнею деталі та електродом, густини струму і температури електроліту. Концентрація активних компонентів електроліту для хромування оцінюється непрямим вимірю- ванням густини електроліту, його електричного опору та водневого показника. Вимірювання швидкості потоку електроліту та його густини здійснюється коріолісовим датчиком. Зовнішній вигляд інтерфейсу системи автоматизованого керування наведено на рис. 1.

Програмне забезпечення дозволяє незалежно контролювати та підтримувати на заданому рівні технологічні параметри процесу електрохімічного хромування, а також за потреби змінювати їх під час електролізу. Максимальна величина струму, яким живиться електрохімічна комірка установки, становить 100 А і підтримується із точністю до 0,01 A. Температура електроліту підтримується вищою за кімнатну і не перевищує $100^{\circ} \mathrm{C}$, із точністю $1^{\circ} \mathrm{C}$. Швидкість потоку електроліту вимірюється в межах до $150 \mathrm{~cm} / \mathrm{c}$, із похибкою не більшою $1 \%$, а гус-

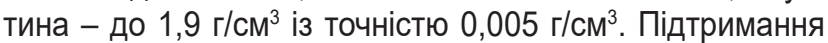
заданих технологічних параметрів здійснюється системою автоматичного керування із використанням пропорційно інтегрованого закону керування.

Як матеріал для виготовлення циліндричних зразків використовували хромонікелеву конструкційну леговану сталь 40ХН (ГОСТ 4543-71), які поверхнево гартували струмами високої частоти. Згідно діючих вимог до стану підготовки поверхні перед нанесенням хромового покриття зразки піддавали шліфуванню $\left(R_{a}=0,32\right.$ мкм). Хромове покриття наносили на зразки зі сталі в стандартному електроліті на основі хромового ангідриду та сірчаної кислоти із нанододатками оксиду алюмінію. Циліндричні аноди сплав свинець-олово-сурма отримували литвом.

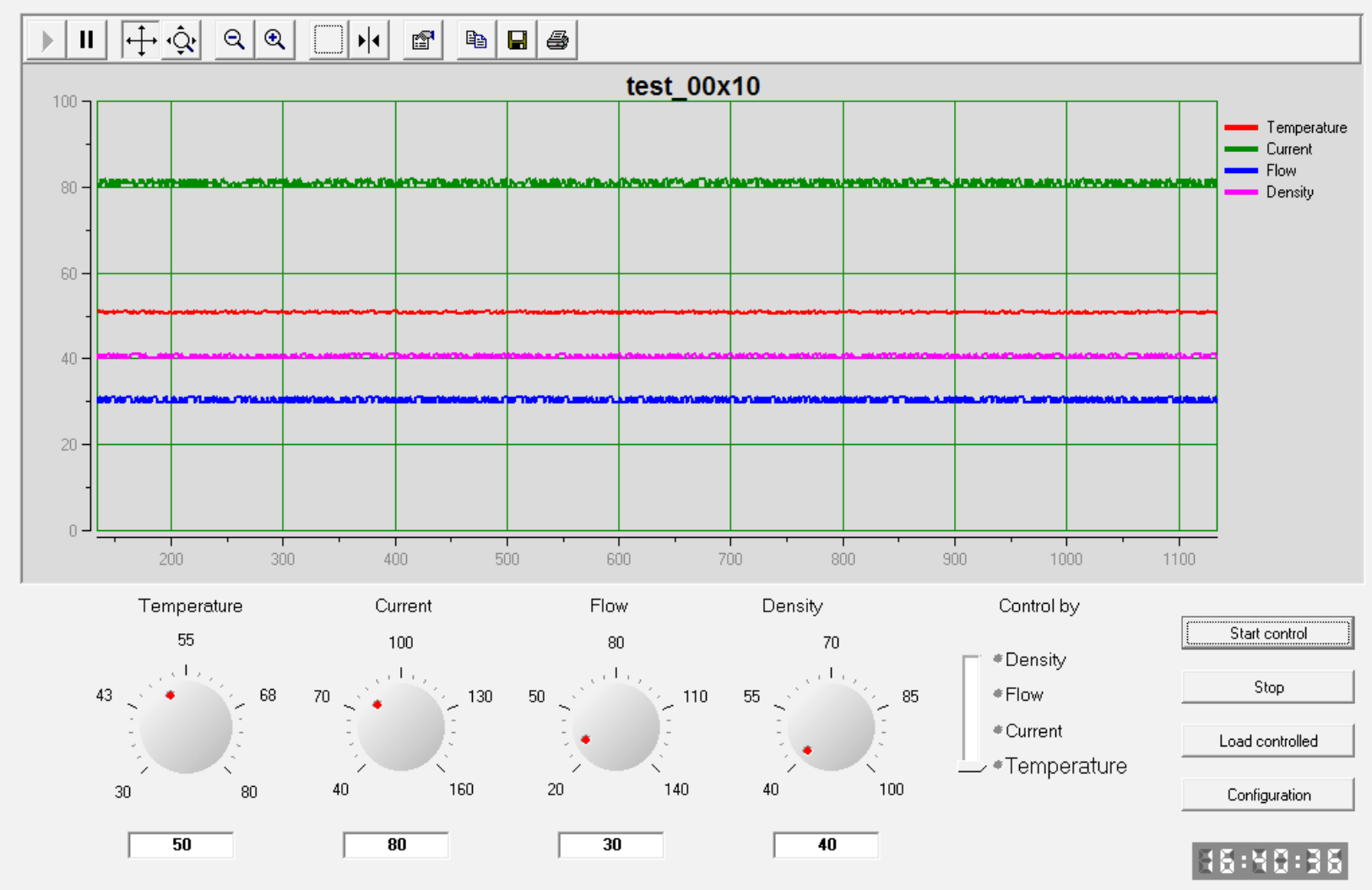

Рис. 1. Загальний вигляд інтерфейсу системи автоматизованого керування технологічними параметрами процесу електрохімічного хромування в проточному електроліті 
Шорсткість поверхні зразків $\left(R_{a}\right)$ визначали розрахунковим методом на підставі результатів обробки профілограм, знятих на модернізованому приладі профілографі-профілометрі моделі Р-201, відповідно перед нанесенням та після нанесення хромових покриттів.

Для вимірювання товщини і мікротвердості хромових покриттів виготовляли мікрошліфи та використовували прилад ПМТ-3. Товщина шару нанесеного хромового покриття становила від 150 мкм до 170 мкм. Випробовування хромованих зразків на зношування проводили на модернізованій установці для дослідження пар тертя при зворотно-поступальному русі в середовищі промивальної рідини з абразивом, яка відтворює реальні умови роботи під час експлуатації металево-гумових пар тертя насосів: циліндрова втулка - гумово-металевий поршень; шток поршня - гумове ущільнення; плунжер - гумове ущільнення. Величину зносу хромованих зразків визначали гравіметричним методом за допомогою аналітичних терезів ВЛР-200.

\section{Результати досліджень}

Під час проведення досліджень електрохімічних хромових покриттів, нанесених у проточному електроліті з нанододатками, експерименти повторювали тричі з визначенням середніх значень. Для побудови математичних моделей взаємозв'язків залежних змінних із вхідними технологічними параметрами було проведено статистичну обробку результатів експерименту із застосуванням методів кореляційно-регресійного аналізу. На першому етапі кореляційного аналізу підтверджено наявність взаємозв'язків між досліджуваними фракторами, а

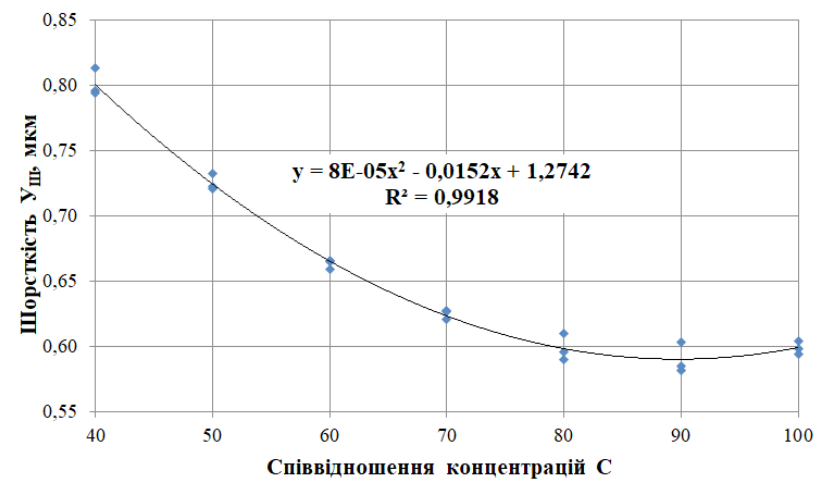

a)

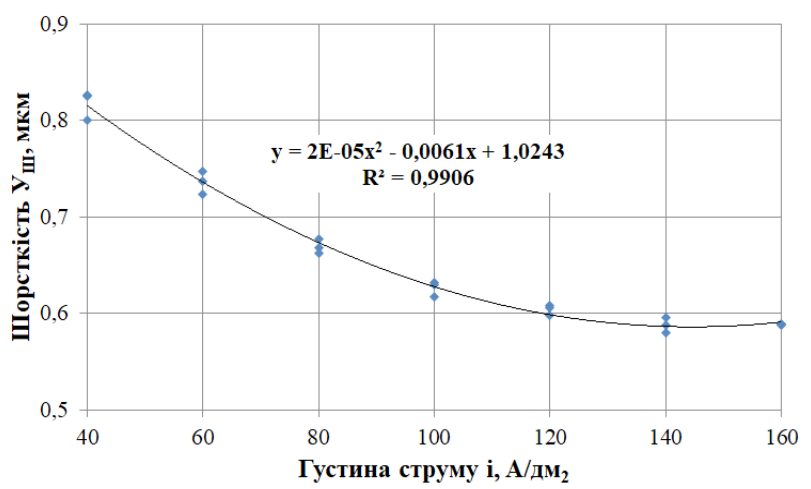

B) на другому - за допомогою регресійного аналізу побудовано поліномінальні математичні моделі другого порядку для всіх залежних змінних (технологічних параметрів). Коефріцієнт детермінації $R^{2}$ для знайдених рівнянь регресії становив від 0,8402 до 0,9927, при цьому коефіцієнт множинної кореляції $R$ знаходився в межах від 0,9166 до 0,9963 . Оскільки значення $R^{2}$ більше 0,8 , то моделі досить коректно описують відповідні залежності та є придатними для подальших розрахунків характеристик хромових покриттів у залежності від величини технологічних параметрів процесу електрохімічного хромування сталевих циліндричних деталей у проточному електроліті.

За результатами експериментальних досліджень будували графрічні залежності величини шорсткості поверхні (рис. 2), мікротвердості (рис. 3) та зносу (рис. 4) електрохімічних хромових покриттів, нанесених у проточному електроліті, від технологічних параметрів процесу: співвідношення концентрацій компонентів електроліту, швидкості потоку, густини струму та температури електроліту. При цьому значення технологічних параметрів процесу електрохімічного хромування приймали в діапазонах: співвідношення концентрацій компонентів електроліту $-C=40-100$ за постійного вмісту 25 г/л частинок $\alpha-\mathrm{Al}_{2} \mathrm{O}_{3}$, швидкість потоку $-v=20-140 \mathrm{~cm} / \mathrm{c}$, густина струму $-i=40-160$ А/дм², температура електроліту $-T=30-80{ }^{\circ} \mathrm{C}$. Під час побудови відповідних грасрічних залежностей решта три технологічні параметри приймали на середньому рівні: співвідношення концентрацій компонентів електроліту $-C=70$, швидкість потоку $-v=100 \mathrm{~cm} / \mathrm{c}$, густина струму $-i=85 \mathrm{~A}_{2 \mathrm{~m}^{2}}$, температура електроліту $-T=55^{\circ} \mathrm{C}$.

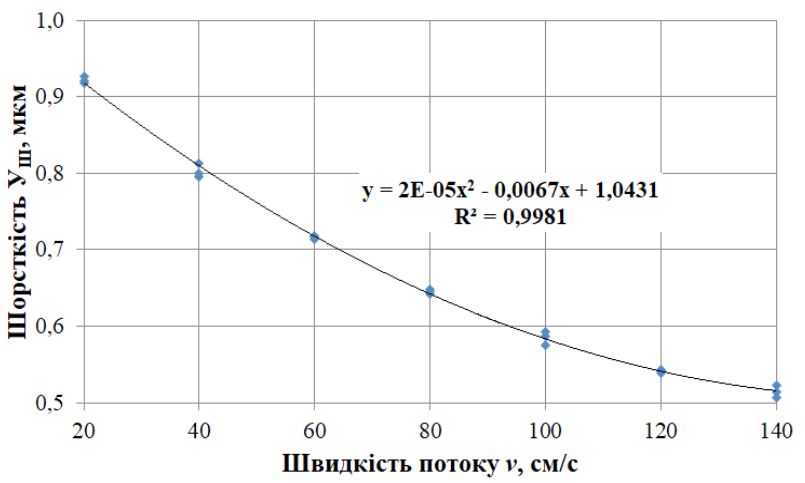

б)

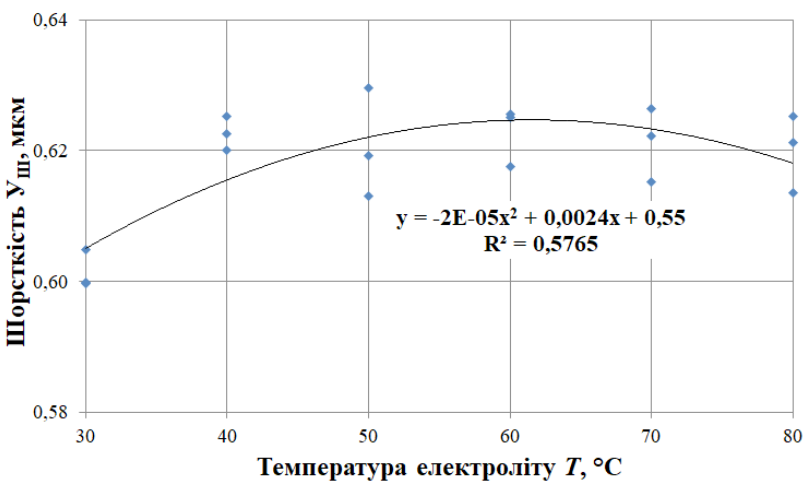

г)

Рис. 2. Залежність шорсткості поверхні покриття від технологічних параметрів процесу електрохімічного хромування в проточному електроліті: а - співвідношення концентрацій компонентів електроліту; б - швидкості потоку; в - густини струму; г - температури електроліту 
Аналіз впливу технологічних параметрів процесу електрохімічного хромування на величину шорсткості поверхні покриття (рис. 2) показав, що представлена на рис. 2, а крива $є$ вгнутою та має мінімум за співвідношення концентрацій компонентів електроліту - $C=90$. Щодо впливу швидкості потоку на шорсткість (рис. 2, б), то отримана крива є спадною у межах досліджуваного діапазону, при цьому досягається мінімальне значення шорсткості покриття на краю, за максимального значень швидкість потоку $-v=140 \mathrm{~cm} / \mathrm{c}$. Отримана крива залежності шорсткості хромового покриття від густини струму (рис. 2, в) є спадною у межах досліджуваного діапазону, а мінімальне значення шорсткості покриття досягається майже на краю, за густини струму близько $i=145$ А/дм². Залежність шорсткості поверхні хромового покриття від температури електроліту (рис. 2, г) є випуклою кривою, а максимальне значення шорсткості покриття досягається за температури електроліту біля $T=60^{\circ} \mathrm{C}$.

Із аналізу результатів дослідження впливу технологічних параметрів процесу електрохімічного хромування на мікротвердість покриття (рис. 3) встановлено, що всі отримані криві $є$ випуклими та мають максимуми в точках відповідно: співвідношення концентрацій компонентнентів електроліту $-C=75$, швидкість потоку $-v=90 \mathrm{~cm} / \mathrm{c}$, густина струму $-i=140 \mathrm{~A} /$ дм $^{2}$, температура електроліту $-T=57^{\circ} \mathrm{C}$. За цих значень технологічних параметрів процесу електрохімічного хромування у досліджу-

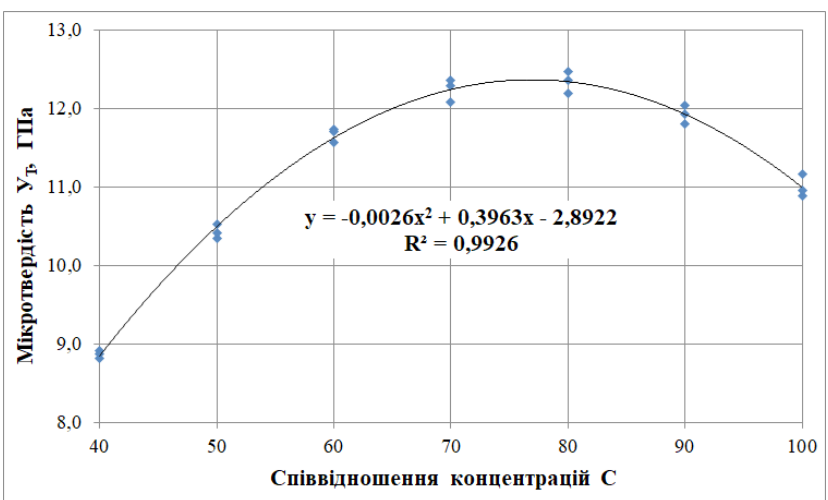

a)

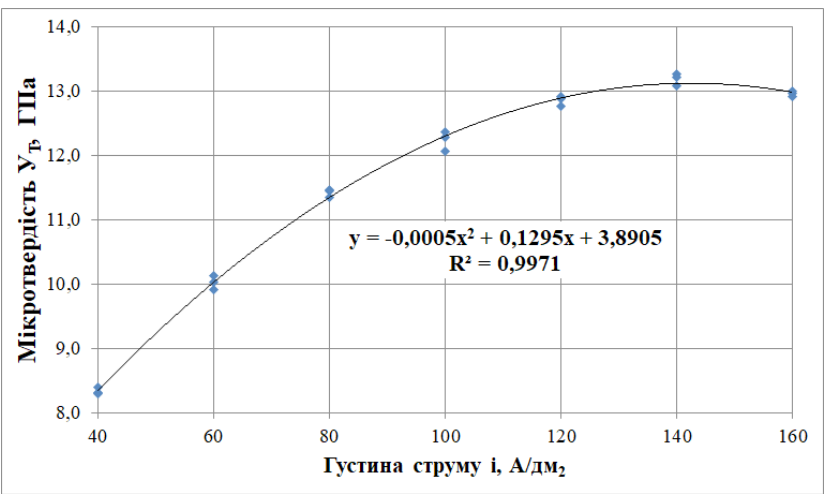

B) ваних діапазонах забезпечується отримання величини мікротвердості покриття від 11,7 ГПа до 13,1 ГПа. При цьому найбільший вплив на величину мікротвердості чинить густина струму, забезпечуючи формування хромового покриття з великою мікротвердістю - 13,1 ГПа.

Аналізуючи вплив технологічних параметрів процесу електрохімічного хромування на величину зносу покриття (рис. 4) слід відзначити, що представлені на рис. 4, a, 6, 6, г криві $€$ вгнутими та мають мінімуми в точках відповідно: співвідношення концентрацій компонентів електроліту $C=80$, швидкість потоку $-v=95 \mathrm{~cm} / \mathrm{c}$, густина струму $i=150 \mathrm{~A} /$ дм $^{2}$, температура електроліту $-T=50^{\circ} \mathrm{C}$. За вищевказаних значень технологічних параметрів процесу електрохімічного хромування у досліджуваних діапазонах величина зносу покриття змінюється від 0,095 г до 0,107 г. Встановлено, що найменша величина зносу хромового покриття досягається під час його формування за густини струму $-i=150 \mathrm{~A} /$ дм² $^{2}$.

\section{Обговорення результатів дослідження}

Аналіз графрічних залежностей шорсткості поверхні (рис. 2), мікротвердості (рис. 3) та зносу (рис. 4) електрохімічних хромових покриттів нанесених у проточному електроліті від технологічних параметрів процесу, свідчить, що показники якості поверхні та фізико-механічні властивості досліджуваних хромових покриттів залежать практично від усіх технологічних параметрів процесу електрохімічного хромування: співвідношення концентрацій

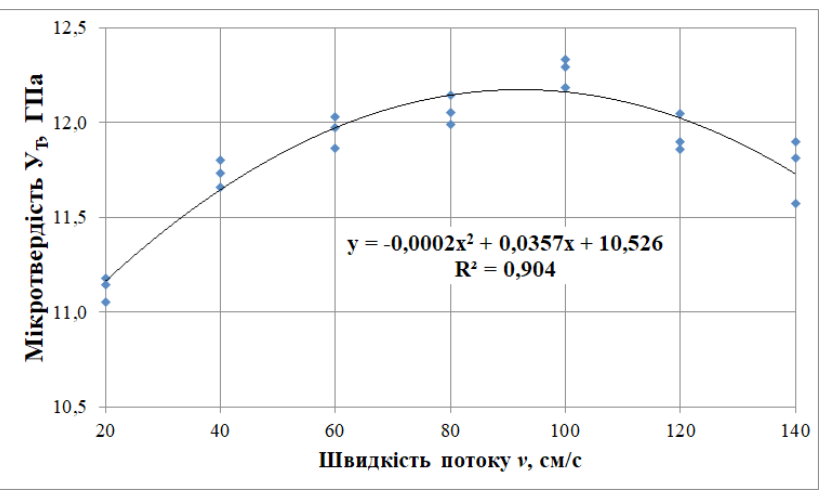

б)

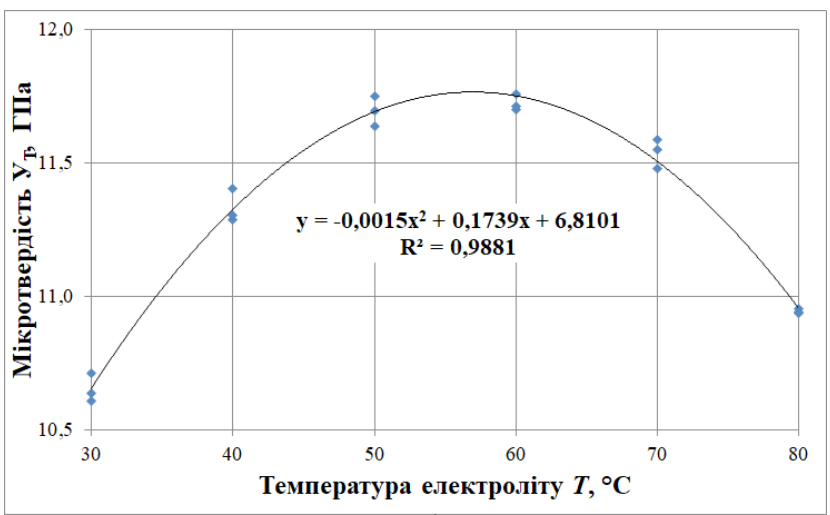

г)

Рис. 3. Залежність мікротвердості покриття від технологічних параметрів процесу електрохімічного хромування в проточному електроліті: a - співвідношення концентрацій компонентів електроліту; б - швидкості потоку; в - густини струму; г - температури електроліту 
компонентів електроліту, швидкості потоку, густини струму, температури електроліту. Зростання величини співвідношення концентрацій компонентів електроліту, швидкості потоку та густини струму призводить до зниження шорсткості, а збільшення температури електроліту спричиняє збільшення шорсткості поверхні хромового покриття. Введення до складу хромового покриття нанооксидів алюмінію призводить до зростання його мікротвердості, що узгоджується із результатами досліджень 3 нанесення композиційних електрохімічних покриттів (Yar-Mukhamedova \& Yar-Mukhamedov, 2012; Bikulčius et al., 2018; Zeng \& Zhang, 2008). Причому збільшення величини мікротвердості хромового покриття практично повною мірою корелює зі зменшенням його зносу.

Слід зазначити, що майже всі отримані криві (рис. 2 рис. 4) є параболічного типу, і більшість із них має критичні (максимум/мінімум) точки в межах досліджуваних діапазонів зміни технологічних параметрів процесу електрохімічного хромування в проточному електроліті. Це свідчить про можливість проведення у подальших дослідженнях оптимізації технологічних параметрів процесу електрохімічного хромування, які забезпечуватимуть високі експлуатаційні властивості деталей поршневих і плунжерних насосів з хромовими покриттями. Одержані нами результати досліджень узгоджується з результатами представленими в працях (Zhang et al., 2013; Bloch \& Geitner, 2019), де описуються приклади зміцнення хро-

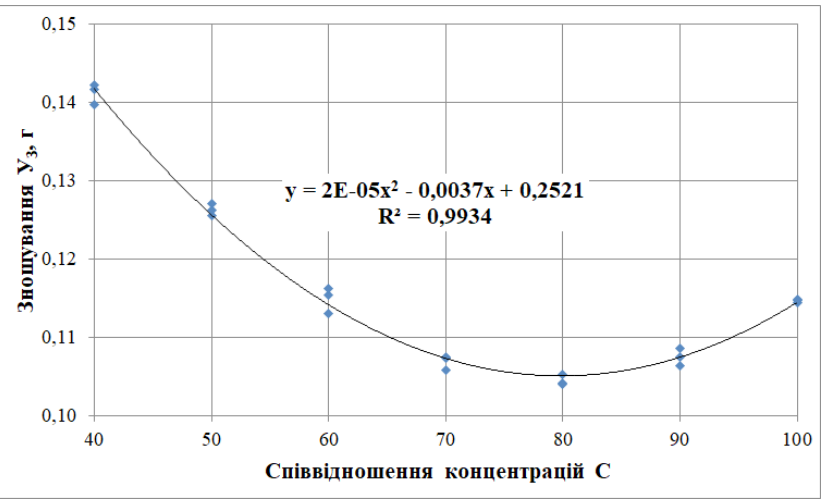

a)

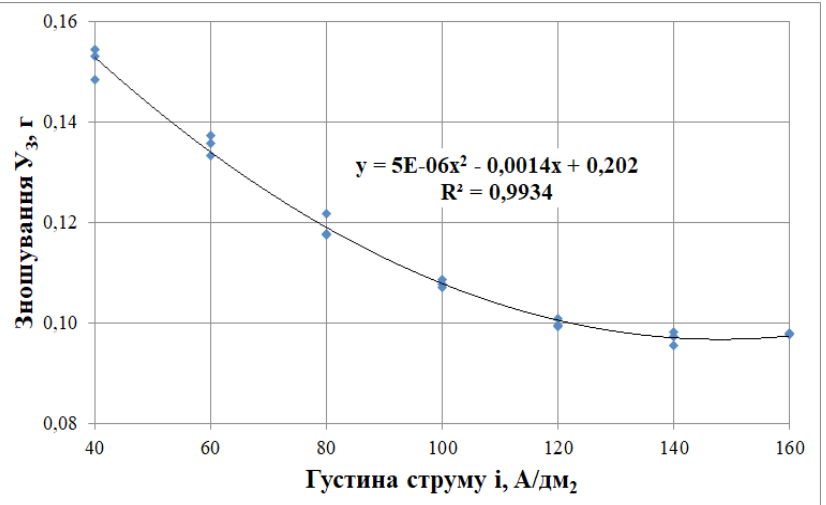

B) муванням відповідно штоків гідроциліндрів і гільз поршневого компресора для забезпечення одержання високої твердості робочої поверхні з низьким коефіцієнтом тертя.

Таким чином, результати досліджень показали можливість цілеспрямованого керування процесом електрохімічного хромування в проточному електроліті задля отримання покриттів із наперед заданими експлуатаційними властивостями, шляхом зміни технологічних параметрів, за допомогою розробленої системи автоматизованого керування. Отримані результати досліджень доцільно використовувати під час розроблення технологічних процесів зміцнення хромовими покриттями деталей поршневих і плунжерних насосів та компресорів тощо.

\section{Висновки}

Розроблено систему автоматизованого керування технологічними параметрами процесу електрохімічного хромування в проточному електроліті, яка забезпечує підтримання на заданому рівні технологічних параметрів процесу: співвідношення концентрацій компонентів електроліту, швидкості потоку, густини струму та температури електроліту, а також дозволяє контролювати водневий показник електроліту та його електричний опір. На підставі результатів проведених експериментальних досліджень побудовано регресійні моделі другого порядку, які описують залежності величини шорсткості поверхні, мікротвердості та зносу електрохімічних хромових покриттів нанесених в проточному електроліті від

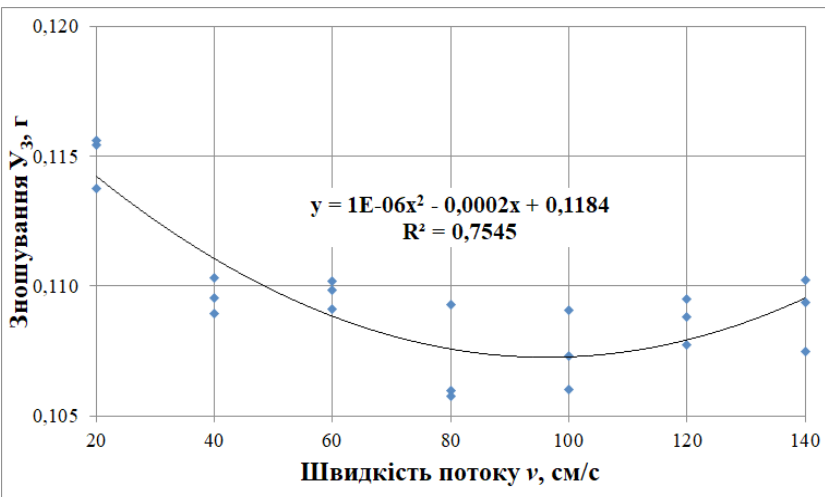

б)

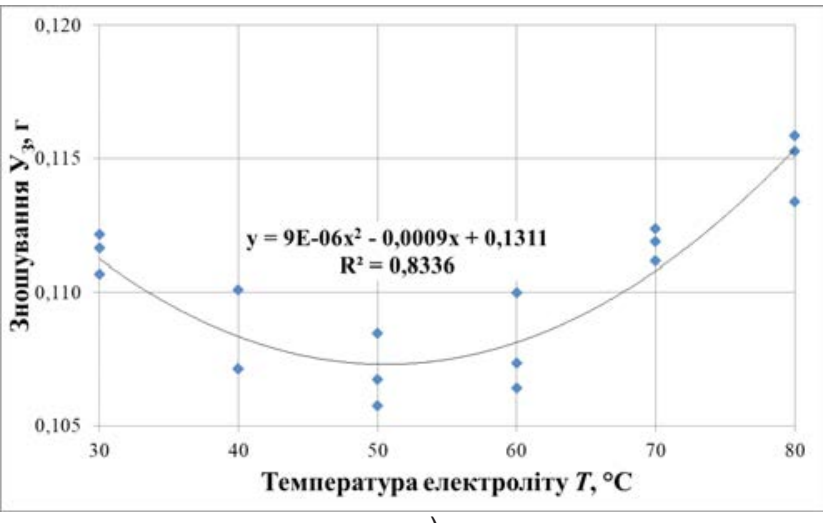

г)

Рис. 4. Залежність величини зносу покриття від технологічних параметрів процесу електрохімічного хромування в проточному електроліті: a - співвідношення концентрацій компонентів електроліту; б - швидкості потоку; в - густини струму; г - температури електроліту 
режимів технологічних параметрів процесу: співвідношення концентрацій компонентів електроліту, швидкості потоку, густини струму та температури електроліту. Встановлено, що зростання величини співвідношення концентрацій компонентів електроліту, швидкості потоку та густини струму призводить до зниження шорсткості, а збільшення температури електроліту спричиняє збільшення шорсткості поверхні хромового покриття. Технологічні параметри процесу електрохімічного хромування практично однаково впливають на збільшення величини мікротвердості та зменшення зношування покриття. Введення до складу хромового покриття нанооксидів алюмінію призводить до зростання його мікротвердості та від- повідно зменшення зносу. Впровадження розробленої технології у виробництво дозволить підвищити ресурс роботи швидкозношуваних деталей машин.

У подальших дослідженнях планується провести оптимізацію технологічного процесу електрохімічного хромування в проточному електроліті з нанододатками.

Подяки. Дослідження проводилося в рамках проекту «Розробка екологічно чистої технології хромування в проточному електроліті довгомірних деталей зі складною топологією поверхні», Д-8-21-П (РК 0121U109591), 2021-2022 р.р., що фрінансується Міністерством освіти і науки України за рахунок видатків загального фонду державного бюджету.

\section{Бібліографічні посилання:}

1. Vinokurov, E.G., Burukhina, T.F., \& Kuroshev, I.S. (2021). Ranking of metallic and non-metallic coatings in the electrochemical surface treatment sector. Tsvetnye Metally, 2021 (4), 54-58. ULR: https://doi.org/10.17580/tsm.2021.04.09.

2. Zhang, N., Huang, C. H., Zhang, C. H., \& Shi, N. (2013). Anticorrosion Property Study on the Hard Chrome Plating Layer of Hydraulic Cylinder Rod. Advanced Materials Research, 791-793, 394-397. Trans Tech Publications, Ltd. ULR: https://doi.org/10.4028/www.scientific.net/amr.791-793.394.

3. Ma, J.-S. (2018). The law of barrel wear and its application. Defence Technology, 14 (6), 674-676. ULR: https://doi.org/10.1016/j.dt.2018.06.012.

4. Li, X.-I., Zang, Y., Lian, Y., Ma, M.-yu., Mu, L., \& Qin, Q. (2021). An interface shear damage model of chromium coating/steel substrate under thermal erosion load. Defence Technology, 17(2), 405-415. ULR: https://doi.org/10.1016/j. dt.2020.02.002.

5. Yusron, R.M., Bisono, R.M., \& Pramudia, M. (2020). Effect Electrolyte Temperature and Electrode Distance to Electroplating Hard-Chrome on Medium-Carbon Steel. Journal of Physics: Conference Series, 1569 (4), art. no. 042007. ULR: https://doi.org/10.1088/1742-6596/1569/4/042007.

6. Jeeva, P.A. (2020). A review on electrodeposition of hard chrome plating. Journal of Corrosion Science and Engineering, 23, art. no. 41, 1-12.

7. Galimov, D.M., Ardashev, D.V., \& Dyakonov, A.A. (2020). Morphology and properties of solid chrome plating, obtained by the galvano-mechanical method. Solid State Phenomena, 299 SSP, 872-878. ULR: https://doi.org/10.4028/www. scientific.net/SSP.299.872.

8. Vinh, P.N., Thien, N.D., Le \& Chi, C. (2018). Study the Effect of Chrome Coating Thickness to Fatigue Strength of the Axle-Shaped Machine Parts. Proceedings 2018 4th International Conference on Green Technology and Sustainable Development, GTSD 2018, art. no. 8595550, 221-226. ULR: https://doi.org/10.1109/GTSD.2018.8595550.

9. Ngon, D.T., Cuong, L.C., \& Phoi, N.V. (2016). Study of the Effect of Chrome Coating Layer to the Fatigue Strength of the Axial Machine Parts. Proceedings - 3rd International Conference on Green Technology and Sustainable Development, GTSD 2016, art. no. 7796635, 135-140. https://doi.org/10.1109/GTSD.2016.40.

10. Xia, H., Shen, X.M., Yang, X.C., Xiong, Y., \& Jiang, G.L. (2018). Influences of the current density on the performances of the chrome-plated layer in deterministic electroplating repair. IOP Conference Series: Materials Science and Engineering, 292 (1), art. no. 012075. ULR: https://doi.org/10.1088/1757-899X/292/1/012075.

11. Danilov, F.I., Protsenko, V.S., Gordiienko, V.O., Baskevich, A.S., \& Artemchuk, V.V. (2013). Electroplating of wearresistant nanocrystalline coatings from a bath containing basic chromium (III) sulfate (chrome tanning agent). Protection of Metals and Physical Chemistry of Surfaces, 49 (3), 299-303. ULR: https://doi.org/10.1134/S2070205113030076.

12. Protsenko, V.S., \& Danilov, F.I. (2014). Chromium electroplating from trivalent chromium baths as an environmentally friendly alternative to hazardous hexavalent chromium baths: Comparative study on advantages and disadvantages. Clean Technologies and Environmental Policy, 16 (6), 1201-1206. ULR: https://doi.org/10.1007/s10098-014-0711-1.

13. Protsenko, V.S., Bobrova, L.S., Baskevich, A.S., Korniy, S.A., \& Danilov, F.I. (2018). Electrodeposition of chromium coatings from a choline chloride based ionic liquid with the addition of water. Journal of Chemical Technology and Metallurgy, $53(5), 906-915$.

14. Bakanov, V.I., Nesterova, N.V., \& Yakupov, A.A. (2017). Features of electroplating of nanocrystalline chromium coatings from electrolytes based on $\mathrm{Cr}(\mathrm{III})$. Protection of Metals and Physical Chemistry of Surfaces, 53 (3), $426-432$. ULR: https://doi.org/10.1134/S2070205117030054.

15. Katirci, R. (2016). A chrome coating from a trivalent chromium bath containing extremely low concentration of $\mathrm{Cr}^{3+}$ ions. International Journal of Surface Science and Engineering, 10(1), 73-85. ULR: https://doi.org/10.1504/ IJSURFSE.2016.075318.

16. Liang, A., Li, Y., Liang, H., Ni, L., \& Zhang, J. (2017). A favorable chromium coating electrodeposited from $\mathrm{Cr}(\mathrm{III})$ electrolyte reveals anti-wear performance similar to conventional hard chromium. Materials Letters, 189, $221-224$. ULR: https://doi.org/10.1016/j.matlet.2016.12.022.

17. Hall, T. D., Snyder, S. T., Taylor, E. J., Inman, M. E., Xu, J., \& Radhakrishnan, R. (2017). Development of a Functional Reach Compliant Trivalent Chromium Electroplating Process. ECS - 2017 The Electrochemical Society, ECS Meeting Abstracts, E01-Green Electrodeposition, 4, MA2017-01, art. no. 1045. ULR: https://doi.org/10.1149/MA2017-01/18/1045.

18. Qi, J., Światowska, J., Skeldon, P., \& Marcus, P. (2020). Chromium valence change in trivalent chromium conversion coatings on aluminium deposited under applied potentials. Corrosion Science, 167, art. no. 108482. ULR: https://doi.org/10.1016/j.corsci.2020.108482.

19. Sherwin, C., Bhat, S., \& Hebbar, S. P. (2020). A brief review on nickel and chromium coatings developed by electrochemical routeю. AIP Conference Proceedings, 2236 (1), art. no. 040007. ULR: https://doi.org/10.1063/5.0006832. 
20. Putri, S., Pujiyanto, E., \& Triyono, J. (2019). Optimization of Electroplating Thickness Quality at Hip Joint Implant Using the Taguchi Method. Jurnal Teknik Industri, 20(1), 45-52. ULR: https://doi.org/10.22219/JTIUMM.Vol20.No1.45-52.

21. Bikulčius, G., Češunienè, A., Selskienè, A., Pakštas, V., \& Matijošius, T. (2017). Dry sliding tribological behavior of $\mathrm{Cr}$ coatings electrodeposited in trivalent chromium sulphate baths. Surface and Coatings Technology, 315, 130-138. ULR: https://doi.org/10.1016/j.surfcoat.2017.01.076.

22. Addach, H., Berçot, P., Rezrazi, M., Petris-Wery, M. De., \& Ayedi, H. F. (2007) Application of statistical design to optimisation of hardness and hydrogen content of chromium coating under pulse reverse electroplating, Transactions of the Institute of Metal Finishing. The International Journal of Surface Engineering and Coatings, 85(4), 187-193. ULR: https://doi.org/10.1179/174591907X216422.

23. Kagajwala, B., Hall, T.D., Inman, M., Taylor, E.J., Griffin, B., Cushnie, G., Taylor, R., Jaworowski, M., \& Bonivel, J. (2013). Functional Trivalent Chromium Electroplating of Internal Diameters. Products Finishing, 1/2/2013. Digital Edition. ULR: https://www.pfonline.com/articles/functional-trivalent-chromium-electroplating-of-internal-diameters.

24. Ropiak L. la. \& Ostapovych V. V. (2016). Optymizatsiia tekhnolohichnykh parametriv protsesu khromuvannia dlia zabezpechennia pokaznykiv yakosti detalei porshnevykh nasosiv. Skhidno-Evropeiskyi zhurnal peredovykh tekhnolohii [Eastern-European Journal of Enterprise Technologies], 2 (5 (80), 50-62. (in Ukrainian). ULR: https://doi.org/10.15587/1 729-4061.2016.65719.

25. Belyaev, V. N., Koslyuk, A. Yu, Lobunets, A. V., \& Andreyev, A. S. (2016). Quality Improvement of Chrome-Diamond Coatings on Flowing Chrome Plating. IOP Conference Series: Materials Science and Engineering, 126 (1), art. no. 012002. ULR: https://doi.org/10.1088/1757-899X/126/1/012002.

26. Sonntag, R., Feige, K., dos Santos, C.B., \& Kretzer, J.P. (2017). Hard chrome-coated and fullerene-doped metal surfaces in orthopedic bearings. Materials, 10 (12), art. no. 1449. ULR: https://doi.org/10.3390/ma10121449.

27. Yar-Mukhamedova, G., \& Yar-Mukhamedov, E. (2012). Investigation of corrosion resistance of chrome based nano-composition coatings in the conditions of oil production. 12th International Multidisciplinary Scientific GeoConference and EXPO - Modern Management of Mine Producing, Geology and Environmental Protection, SGEM $2012,3,475-479$.

28. Bikulčius, G., Češǔnienè, A., Selskienè, A., Grigucevičienè, A., Jasulaitienè, V., \& Ger, M. (2018). Characterization of $\mathrm{Cr}-\mathrm{ZrO}$, composite coatings electrodeposited from $\mathrm{Cr}$ (III) bath. Chemija, 29 (2), 97-108. ULR: https://doi.org/10.6001/ chemija.v29i2.3712.

29. Zeng, Z., \& Zhang, J. (2008). Electrodeposition and tribological behavior of amorphous chromium-alumina composite coatings. Surface and Coatings Technology, 202(12), 2725-2730. ULR: https://doi.org/10.1016/j.surfcoat.2007.10.008.

30. Bloch, H. P., \& Geitner, F. K. (2019). Chapter 10 - Protecting machinery parts against the loss of surface. Editor(s): Heinz P. Bloch, Fred K. Geitner. In Practical Machinery Management for Process Plants. Machinery Component Maintenance and Repair (Fourth Edition). Gulf Professional Publishing, 2019, 551-633. ULR: https://doi.org/10.1016/ B978-0-12-818729-6.00010-1.

Ropyak L. Ya., Doctor of Technical Sciences, Professor, Ivano-Frankivsk National Technical University of Oil and Gas, Ivano-Frankivsk, Ukraine

Shovkoplias M. V., Postgraduate, Ivano-Frankivsk National Technical University of Oil and Gas, Ivano-Frankivsk, Ukraine

Vytvytskyi V. S., Candidate of Technical Sciences, Associate Professor, Ivano-Frankivsk National Technical University of Oil and Gas Ivano-Frankivsk, Ukraine

Striletskyi Y. Y., Doctor of Technical Sciences, Professor, Ivano-Frankivsk National Technical University of Oil and Gas, Ivano-Frankivsk, Ukraine

Influence of technological parameters the electrochemical chromiation process on the operational properties of coatings

The analysis of chrome plating methods to increase the wear-resistance and corrosion resistance of replaceable parts of the hydraulic part of piston pumps: piston rods, rod extensions, plungers and cylinder bushings. Reasoned the advantages of using electrochemical chrome plating of parts in a flowing electrolyte with nanoadditives, which provides wear-resistant coatings with stable surface quality indicators and high physical and mechanical properties. An automated control system has been developed which provides maintain at a given level the technological parameters of the electrochemical chromium plating process in a flowing electrolyte: the ratio of concentrations of electrolyte components, flow rate, current density and electrolyte temperature, and also allows to control the value of the water index of the electrolyte and its electrical resistance. The application of a chromium coating of a standard electrolyte with nanoadditives on the 40HN steel samples, which were surface hardened and ground, have investigated. Surface roughness, thickness and microhardness of coating were determined. Chrome-plated samples were tested for wear during reciprocating motion. The value of wearing was determined by gravimetric method. Statistical results of the experiment were performed using correlation-regression analysis. The effect of mass ratio of concentrations of electrolyte components, current density, electrolyte flow rate and electrolyte temperature on the value of roughness, microhardness and wear of coatings was investigated. Second-order regression models that describe the dependences of the surface roughness, microhardness and wear of chrome coatings on the technological parameters of the process was constructed. Increasing a ratio of the concentrations of the electrolyte components, flow rate and current density leads to a decrease in roughness, and an increase in the electrolyte temperature causes an increase in the roughness of the chromium coating was established. Technological parameters of the chromium plating process have almost the same effect on increasing the microhardness and reducing the wear of the coating, and the introduction of aluminum nanooxides in the chromium coating leads to an increase in its microhardness and, accordingly, reduce wear.

Key words: electrochemical chrome coating, flowing electrolyte, technological parameters, long details, automated control system, roughness, microhardness, wear.

Дата надходження 24.11.2022 p. 